\title{
Biomass and elemental composition of eggs and larvae of a mangrove crab, Sesarma rectum Randall (Decapoda: Sesarmidae) and comparison to a related species with abbreviated larval development*
}

\author{
KLAUS ANGER ${ }^{1}$ and GLORIA S. MOREIRA ${ }^{2}$ \\ ${ }^{1}$ Biologische Anstalt Helgoland, Stiftung Alfred-Wegener-Institut für Polar- und Meeresforschung, 27498 Helgoland, \\ Germany. E-mail: kanger@awi-bremerhaven.de \\ ${ }^{2}$ Universidade de São Paulo, Instituto de Biociências, 05422-970 São Paulo, SP, Brazil.
}

\begin{abstract}
SUMMARY: We measured biomass and elemental composition (dry mass, W; carbon, hydrogen, nitrogen, CHN) in eggs and larvae of a mangrove crab, Sesarma rectum. The results are compared with previously published data from a closely related species with abbreviated development ( $S$. curacaoense). Egg size of $S$. rectum increased during embryogenesis, while egg biomass, $\mathrm{C}$ content $(\% \mathrm{~W})$, and the $\mathrm{C}: \mathrm{N}$ ratio decreased. Initial biomass of eggs and larvae in $S$. rectum was about half of that in $S$. curacaoense, also showing lower percentage values of $\mathrm{C}$ and $\mathrm{H}$ and a lower C:N ratio (indicating a lower lipid content). After hatching, however, the zoeae of $S$. rectum showed higher growth rates than those of $S$. curacaoense (presumably due to partial utilisation of internal energy reserves in the latter) and a longer period of development to the megalopa (passing though three vs. only two zoeal stages); as a consequence of these differential growth patterns, S. rectum compensated for the initially lower biomass. Interspecific comparison among neotropical Sesarmidae suggests an intermediate degree of dependence on planktonic food sources in S. rectum, which is lower than in estuarine species with small eggs and an extended mode of development (e.g. Armases angustipes), but higher than in relatives with larger egg biomass and an abbreviated development (e.g. A. miersii, S. curacaoense, S. fossarum, Metopaulias depressus). This should allow S. rectum larvae to develop partially within the parental mangrove system, but requiring a limited export towards coastal marine waters with planktonic food sources.
\end{abstract}

Key words: decapod crustacean, larvae, abbreviated development, growth, carbon, nitrogen.

RESUMEN: BIOMASA Y COMPOSICIÓN ELEMENTAL DE LOS HUEVOS Y LAS LARVAS DE UN CANGREJO DE MANGLAR, SESARMA RECTUM RANDALl (DECAPODA: SESARMIDAE) Y COMPARACIÓN CON UNA ESPECIE PRÓXIMAMENTE RELACIONADA CON DESARROLLO LARVARIO ABREVIADO. - En un cangrejo de manglar, Sesarma rectum, medimos la biomasa y composición elemental (masa seca, W; carbono, hidrógeno, nitrógeno, $\mathrm{CHN}$ ) de los huevos y las larvas y comparamos los resultados con datos de una especie próximamente relacionada con desarrollo abreviado (S. curacaoense). El tamaño de huevo de S. rectum aumentó durante la embriogénesis, mientras la biomasa, el contenido de $\mathrm{C}$ (en \% de $\mathrm{W}$ ) y la relación C:N disminuyeron. La biomasa inicial de los huevos y las larvas fue la mitad que en $S$. curacaoense, mostrando también bajos porcentajes de $\mathrm{C}$ y $\mathrm{H}$ y una relación de C:N baja (indicando contenidos más bajos de lípidos). S. rectum mostró tasas más altas de crecimiento larval que $S$. curacaoense (probablemente debido a una utilización parcial de reservas internas en la segunda), compensando así las diferencias en biomasa inicial. La comparación interespecífica entre Sesarmidae neotropicales sugiere en S. rectum un grado intermedio de dependencia de fuentes planctónicas de alimento, siendo más baja que en especies estuariales con huevos pequeños y un modo extendido de desarrollo (por ejemplo Armases angustipes), pero más alto que en especies cercanas con biomasa de huevo más grande y desarrollo abreviado (p.e. A. miersii, S. curacaoense, S. fossarum, Metopaulias depressus). Esto debe permitir que las larvas de S. rectum se desarrollen parcialmente dentro del habitat parental en el manglar, aunque requiriendo una exportación limitada hacia aguas costeras marinas con fuentes planctónicas de alimento.

Palabras clave: crustáceos decápodos, larvas, desarrollo abreviado, crecimiento, carbono, nitrógeno.

*Received November 11, 2002. Accepted September 10, 2003. 


\section{INTRODUCTION}

Grapsoid crabs, in particular those of the family Sesarmidae (formerly subfamily Sesarminae, family Grapsidae; for recent major changes in the taxonomy of the Grapsoidea, see Schubart et al., 2000, 2002), show a general tendency to invade nonmarine environments such as brackish, freshwater, and terrestrial habitats (for review, see Anger, 2001). This life style requires physiological adaptations not only in the adult crabs, namely euryhalinity and/or resistance against desiccation, but frequently also adaptive traits in the early life-history stages. These include an enhanced female energy investment in the production of large yolky eggs and an abbreviation of the pelagic larval phase, commonly associated with an enhanced initial biomass of eggs and larvae. Unusually high carbon contents and high carbon:nitrogen ratios in the early life-history stages reflect enhanced lipid reserves. These allow for at least partial larval independence from planktonic food sources and thus for development in nonmarine habitats with low or unpredictable plankton production.

Inferring from adult ecology, it may be expected that the semiterrestrial crab Sesarma rectum Randall follows this reproductive strategy. This species is a common inhabitant of the fringing (i.e. relatively dry) zones of mangrove swamps occurring along the South American Atlantic coasts (Gerlach, 1958; Coelho, 1966; Fimpel, 1975). Apart from its larval morphology (Fransozo and Hebling, 1986) and juvenile growth (Fransozo, 1986/87), nothing is known about its early life-history stages, and no data whatsoever exist on larval behaviour, ecology, biomass, chemical composition or growth. It is unknown whether the larvae of this species are retained within the parental mangrove habitat or exported to adjacent coastal waters. While a retention should be based on specific larval adaptations such as an early appearance of osmoregulatory capabilities (Charmantier, 1998; Charmantier et al., 1998, 2002; Anger and Charmantier, 2000, Anger, 2003) and an enhanced biomass at hatching (Anger, 2001), an export strategy would not necessarily require such adaptive traits as are needed for development in a land-locked habitat with unpredictable conditions of salinity and food availability.

In the present study, we measured the initial biomass and elemental composition (dry mass, contents of carbon, hydrogen, nitrogen) of the eggs and lar- vae of Sesarma rectum, and we further followed the ontogenetic changes occurring in these parameters from hatching to metamorphosis. The patterns of larval growth as well as exuvial biomass losses in successive larval stages are compared with those previously reported for the congener $S$. curacaoense DeMan (Anger and Schultze, 1995). Although these species are phylogenetically close to each other (Schubart et al., 2000), they differ in various ecological and life-history traits which are briefly summarised below.

$S$. rectum produces relatively large eggs and larvae which pass through only three zoeal stages and a megalopa (Fransozo and Hebling, 1986), while most other Sesarmidae produce smaller eggs and have at least four zoeal stages (Gore, 1985, Rabalais \& Gore, 1985, Anger, 2001). It thus shows an abbreviated mode of larval development as compared to that in most species of other genera belonging to the family Sesarmidae, which is probably typical of neotropical Sesarma spp. (Costlow and Bookhout, 1962; Zimmerman and Felder, 1991). On the other hand, its development may be considered as "extended" (for terminology, see Gore, 1985) compared to congeners which have further reduced their larval phase to only two zoeal stages and a megalopa. This appears to be typical, for instance, of a group of endemic species living on the island of Jamaica, where an adaptive radiation has resulted in the evolution of several fully limnic and terrestrial crabs (see Hartnoll, 1964, Schubart et al., 1998, 2000, Anger, 2001). Morphological and molecular genetic evidence indicates that all these species have originated from a common ancestor which was closely related to $S$. curacaoense (see Hartnoll, 1964, Schubart et al., 1998). Living in brackish coastal mangrove habitats of the Caribbean region and northeastern South America, this semi-terrestrial crab is ecologically similar to $S$. rectum (Hartnoll, 1965, Abele, 1973, Wilson, 1989). However, S. curacaoense has a further abbreviated larval development with only two zoeal stages (Anger et al., 1995), and these show an enhanced initial biomass (Anger and Schultze, 1995) and facultative lecithotrophy, while the subsequent megalopa stage is planktotrophic (Anger, 1995).

In summary, the principal aim of the present study was to compare the biomass of eggs and freshly-hatched larvae as well as larval growth in a largely unknown crab species, $S$. rectum, with developmental traits in a close relative that exhibits a more abbreviated mode of development, S. curacaoense. 
These life-history traits may reflect differential degrees of larval dependence or independence from planktonic food sources and should thus indicate strategies of larval export to coastal marine regions or a retention within the mangrove habitats where the adults of these crab species live respectively.

\section{MATERIALS AND METHODS}

On February 7, 1996, seven ovigerous females (carapace width: $21.5-26.0 \mathrm{~mm}$ ) of Sesarma rectum were collected from their typical habitat, deep burrows that the crabs had constructed in almost dry sandy soil at the upper margin of a mangrove swamp near Bertioga (State of São Paulo, Brazil). Water temperature and salinity in shallow mangrove pools near the site of collection were $30^{\circ} \mathrm{C}$ and $14 \%$ respectively. The females were transferred to the São Sebastião Marine Biological Station of the University of São Paulo (CEBIMAR), and maintained in aquaria with aerated water $\left(25^{\circ} \mathrm{C}, 25 \%\right.$ o salinity $)$.

Egg size (largest diameter; $n=10$ eggs) was determined in samples taken from all seven ovigerous females. The measurements were made to the nearest $0.01 \mathrm{~mm}$ under a dissecting microscope (Wild M3B) equipped with a calibrated eye piece micrometer. Five egg batches were in an early stage of embryonic development, with yolk occupying more than $80 \%$ of the egg volume and no eye pigments, segmentation, or other signs of embryonic differentiation visible. In two other females, the eggs were in an intermediate developmental stage with visible yet incompletely developed eyes, clear segmentation, heart beat (mostly irregular), and yolk occupying about two thirds of the egg volume. An additional sample of eggs in an intermediate stage of embryonic development was obtained later (21 days after the collection of females) from one of the clutches that had previously been sampled in an early stage of development. In five females, the larvae hatched before the end of our stay at the CEBIMAR laboratory (28 February). From two of these egg clutches that had reached an advanced developmental stage, we took samples 1-2 days before hatching. In total, egg size was thus measured in five samples of eggs in an early, three in an intermediate, and two in the final (prehatching) stage of embryonic development. The latter was characterised by complete embryonic differentiation, regular heart beat, completely formed eyes and larval movements within the egg membrane.

From three females with eggs in different stages of embryonic development (early, intermediate, late) we also removed samples of eggs for later determinations of dry mass (W) and elemental composition (carbon, C; hydrogen, $\mathrm{H}$; nitrogen, $\mathrm{N}$; collectively referred to as $\mathrm{CHN}$; for details of sample treatment and elemental analysis, see below). Likewise, samples of freshly hatched zoeae were taken from all seven females for later CHN measurements.

Two ovigerous females were transferred to the Helgoland Marine Biological Station (Germany) and subsequently kept at constant conditions of $24^{\circ} \mathrm{C}, 25 \%$ salinity, and an artificial $12: 12 \mathrm{~h}$ light:dark cycle. Hatching occurred in both females on March 31, 52 days after collection of the females. The larvae of one female were massreared in bowls with ca. $400 \mathrm{ml}$ diluted seawater (initial density: 50 individuals per bowl) at the same conditions of temperature, salinity and light described above. Water and food (freshly hatched Artemia spec., ca. 10 nauplii $/ \mathrm{ml}$ ) were changed daily, and the larvae were checked for moulting and mortality. Freshly moulted larvae were removed from the cultures and placed in separate rearing containers, so that each bowl contained exclusively individuals that had reached the same larval stage on the same day, thus being approximately in the same stage of the moulting cycle. The rearing salinity $(25 \%$ ) was obtained by dilution of filtered natural seawater from the North Sea $(32 \%$ ) with deionised water; this condition of reduced salt concentration was chosen to simulate larval development in brackish coastal mangrove swamps. The rearing methods for the semibenthic megalopae differed from those of the planktonic zoeae only in that nylon gauze $(0.3 \mathrm{~mm}$ mesh size $)$ was provided as an artificial substrate and in that the rearing density was reduced to a maximum of 20 individuals per bowl.

Samples for measurements of larval growth and elemental composition were taken in daily intervals (zoeal stages) or every 1-2 days (megalopa; see Table 2). When moults to successive larval stages occurred, exuviae were also sampled and stored frozen for later determinations of W and CHN. High mortality in the megalopa stage precluded the study of early juvenile growth, and no data on exuvial biomass were obtained for the megalopa stage.

The following standard techniques were applied: samples were removed from cultures with wide- 
bore pipettes. They were then rinsed briefly in distilled water, blotted on fluff-free Kleenex paper for optical use, frozen for storage at $-20^{\circ} \mathrm{C}$ in preweighed tin cartridges, freeze-dryed in a Lyovac GT-2E vacuum apparatus, weighed to the nearest $0.1 \mu \mathrm{g}$ on a Mettler UM-3 microbalance, and analysed for CHN with a Fisons (Carlo Erba) model EA 1108 Elemental Analyser using acetanilid as a standard. All analyses of egg or larval $\mathrm{W}$ and $\mathrm{CHN}$ comprised 5 replicate measurements, each comprising 2 (megalopa stage) to 15 (early zoeae, eggs) pooled individuals; the number of individuals per replicate depended on $\mathrm{W}$ to meet the requirements for optimal accuracy of the analyser. Determinations of exuvial biomass and composition were made with 100 (stages zoea II-III) or 130 (zoea I) exuviae per replicate analysis. Mean values and standard deviations $( \pm \mathrm{SD})$ were calculated from $\mathrm{n}=5$ replicate determinations.

Ovigerous females of Sesarma curacaoense were collected in 1991 in Jamaica, West Indies (for details of collection and rearing, see Anger and Schultze, 1995). Samples of eggs and freshly hatched larvae were taken and processed as described for $S$. rectum.

All statistical analyses followed standard techniques (Sokal and Rohlf 1995), using JMP version 3.2.6 (SAS Institute Inc.). Data are presented as mean \pm one SD. When data deviated significantly from a normal distribution (Kolmogorov-Smirnov test) or when variances deviated significantly from homogeneity (Levene's median test), the non-parametric Mann-Whitney rank sum test (U-test) was used for comparisons of mean values; otherwise Student's t-test. In multiple comparisons, one-way ANOVA or the non-parametric Kruskal-Wallis Htest was employed respectively. Percentage values $(\mathrm{CHN}$ in \% of $\mathrm{W})$ and ratios $(\mathrm{C}: \mathrm{N})$ were $\operatorname{arc}-\sin$ transformed prior to statistical analysis.

\section{RESULTS}

\section{Remarks on reproduction and embryogenesis of Sesarma rectum}

Microscopic examination of eggs from ovigerous Sesarma rectum immediately after collection from the field showed that some egg batches were at an initial or early stage of embryonic development. The latest hatching occurred 52 days later, indicating the minimal duration of embryogenesis at $24-25{ }^{\circ} \mathrm{C}$. Although females were maintained in aquaria with males, no copulation or new egg laying was observed after hatching of the original egg mass.

\section{Size, biomass, and elemental composition of eggs}

At an initial stage of embryonic development, the mean egg size of Sesarma rectum varied insignificantly among egg clutches, ranging in five females from $500.5 \pm 3.7$ to $505.0 \pm 5.3 \mu \mathrm{m}(\mathrm{n}=10$ eggs each). The overall mean value was $503.2 \pm 1.8 \mu \mathrm{m}(\mathrm{n}=5$ females). Eggs at an intermediate stage showed much higher variability within an egg clutch, with average diameters of $537.0 \pm 16.7,542.9 \pm 18.5$, and $588.5 \pm 16.8 \mu \mathrm{m}$ in three females. Late eggs (obtained from 2 females) had mean egg sizes of 585.0 26.9 and $603.5 \pm 13.6 \mu \mathrm{m}$. Hence, egg size increased during the course of embryonic development by about $100 \mu \mathrm{m}$ or $20 \%$. This corresponds to an increase in volume from 0.065 to $0.113 \mathrm{~mm}^{3}(73 \%)$.

Biomass and elemental composition $(\mathrm{CHN})$ of eggs obtained from different females of $S$. rectum and $S$. curacaoense are compared in Table 1. Data for eggs at an intermediate embryonic stage were available only for $S$. rectum. The individual dry mass (W) and contents of carbon $(\mathrm{C})$, nitrogen $(\mathrm{N})$, and hydrogen $(\mathrm{H})$ per egg as well as the $\mathrm{C}: \mathrm{N}$ mass ratio showed in $S$. rectum decreasing tendencies from early to

TABLE 1. - Biomass, elemental composition (dry mass, W; carbon, C; nitrogen, N; hydrogen, H; C:N mass ratio) of eggs of two Sesarmidae species (sampled from different females, partly in different stages of embryonic development); $\mathrm{x} \pm \mathrm{SD}$, mean \pm 1 standard deviation ( $\mathrm{n}=5$ ).

\begin{tabular}{|c|c|c|c|c|c|c|c|c|c|c|c|c|c|c|c|c|}
\hline $\begin{array}{l}\text { Eggs } \\
\text { (embr. stage) }\end{array}$ & \multicolumn{2}{|c|}{$\mathrm{W}(\mu \mathrm{g} /$ ind $)$} & \multicolumn{2}{|c|}{$\mathrm{C}(\mu \mathrm{g} / \mathrm{ind})$} & \multicolumn{2}{|c|}{$\mathrm{N}(\mu \mathrm{g} / \mathrm{ind})$} & \multicolumn{2}{|c|}{$\mathrm{H}(\mu \mathrm{g} /$ ind $)$} & \multicolumn{2}{|c|}{$\mathrm{C}(\% \mathrm{~W})$} & \multicolumn{2}{|c|}{$\mathrm{N}(\% \mathrm{~W})$} & \multicolumn{2}{|c|}{$\mathrm{H}(\% \mathrm{~W})$} & \multicolumn{2}{|c|}{$\begin{array}{c}\mathrm{C}: \mathrm{N} \text { ratio } \\
\mathrm{X} \quad \pm \mathrm{SD}\end{array}$} \\
\hline $\begin{array}{l}\text { S. curacaoense } \\
\text { (early) } \\
\text { (early) } \\
\text { (late) }\end{array}$ & $\begin{array}{l}58.8 \\
55.7 \\
65.6\end{array}$ & $\begin{array}{l}5.2 \\
1.8 \\
2.7\end{array}$ & $\begin{array}{l}33.8 \\
33.1 \\
35.7\end{array}$ & $\begin{array}{l}3.1 \\
1.1 \\
5.7\end{array}$ & $\begin{array}{l}5.15 \\
5.00 \\
5.58\end{array}$ & $\begin{array}{l}0.49 \\
0.16 \\
0.30\end{array}$ & $\begin{array}{l}5.10 \\
5.06 \\
5.95\end{array}$ & $\begin{array}{l}0.52 \\
0.18 \\
0.93\end{array}$ & $\begin{array}{l}57.5 \\
59.4 \\
54.5\end{array}$ & $\begin{array}{l}0.2 \\
0.1 \\
0.8\end{array}$ & $\begin{array}{l}8.8 \\
9.0 \\
8.5\end{array}$ & $\begin{array}{l}0.1 \\
0.0 \\
0.6\end{array}$ & $\begin{array}{l}8.7 \\
9.1 \\
9.1\end{array}$ & $\begin{array}{l}0.1 \\
0.1 \\
1.4\end{array}$ & $\begin{array}{l}6.56 \\
6.62 \\
6.37\end{array}$ & $\begin{array}{l}0.09 \\
0.03 \\
0.65\end{array}$ \\
\hline
\end{tabular}


TABLE 2. - Biomass, elemental composition (dry mass, W; carbon, C; nitrogen, N; hydrogen, H; C:N mass ratio) of freshly hatched (0 days) zoea I larvae of two Sesarmidae species; intraspecific variability among different females (F1-F7); \pm SD, mean \pm 1 standard deviation ( $\mathrm{n}=5$ ).

\begin{tabular}{|c|c|c|c|c|c|c|c|c|c|c|c|c|c|c|c|c|}
\hline \multirow{2}{*}{$\begin{array}{l}\text { Zoea I (0 d) } \\
\text { Female \# }\end{array}$} & \multicolumn{2}{|c|}{$\mathrm{W}$ ( $\mu \mathrm{g} / \mathrm{ind})$} & \multicolumn{2}{|c|}{$\mathrm{C}(\mu \mathrm{g} / \mathrm{ind})$} & \multicolumn{2}{|c|}{$\mathrm{N}(\mu \mathrm{g} / \mathrm{ind})$} & \multicolumn{2}{|c|}{$\mathrm{H}(\mu \mathrm{g} / \mathrm{ind})$} & \multicolumn{2}{|c|}{$\mathrm{C}(\% \mathrm{~W})$} & \multicolumn{2}{|c|}{$\mathrm{N}(\% \mathrm{~W})$} & \multicolumn{2}{|c|}{$\mathrm{H}(\% \mathrm{~W})$} & \multicolumn{2}{|c|}{$\mathrm{C}: \mathrm{N}$ ratio } \\
\hline & $x$ & $\pm \mathrm{SD}$ & $x$ & $\pm \mathrm{SD}$ & $\mathrm{x}$ & $\pm \mathrm{SD}$ & $\mathrm{x}$ & $\pm \mathrm{SD}$ & $\mathrm{x}$ & $\pm \mathrm{SD}$ & $\mathrm{x}$ & $\pm \mathrm{SD}$ & $\mathrm{x}$ & $\pm \mathrm{SD}$ & $\mathrm{x}$ & $\pm \mathrm{SD}$ \\
\hline \multicolumn{17}{|l|}{ S. rectum } \\
\hline F1 & 27.4 & 0.9 & 11.5 & 0.2 & 2.43 & 0.03 & 1.67 & 0.04 & 41.8 & 0.9 & 8.9 & 0.2 & 6.1 & 0.3 & 4.72 & 0.05 \\
\hline $\mathrm{F} 2$ & 27.0 & 0.6 & 12.2 & 0.2 & 2.55 & 0.13 & 1.89 & 0.05 & 45.1 & 0.8 & 9.5 & 0.3 & 7.0 & 0.2 & 4.78 & 0.22 \\
\hline $\mathrm{F} 3$ & 25.6 & 0.1 & 11.5 & 0.1 & 2.40 & 0.04 & 1.78 & 0.01 & 44.9 & 0.3 & 9.4 & 0.1 & 6.9 & 0.1 & 4.80 & 0.03 \\
\hline $\mathrm{F} 4$ & 25.4 & 0.8 & 11.8 & 0.3 & 2.44 & 0.04 & 1.77 & 0.04 & 46.4 & 0.3 & 9.6 & 0.2 & 7.0 & 0.1 & 4.82 & 0.07 \\
\hline F5 & 23.7 & 0.4 & 10.8 & 0.2 & 2.30 & 0.03 & 1.56 & 0.05 & 45.6 & 0.2 & 9.7 & 0.1 & 6.6 & 0.1 & 4.70 & 0.06 \\
\hline F6 & 25.3 & 0.7 & 10.2 & 0.3 & 2.36 & 0.07 & 1.43 & 0.05 & 40.2 & 0.3 & 9.3 & 0.1 & 5.7 & 0.1 & 4.30 & 0.02 \\
\hline F7 & 21.2 & 0.3 & 9.7 & 0.1 & 2.24 & 0.02 & 1.45 & 0.02 & 45.7 & 1.0 & 10.6 & 0.2 & 6.9 & 0.2 & 4.32 & 0.02 \\
\hline \multicolumn{17}{|c|}{ S. curacaoense } \\
\hline F1 & 53.3 & 2.9 & 23.6 & 1.1 & 4.48 & 0.27 & 3.37 & 0.18 & 44.2 & 1.2 & 8.4 & 0.2 & 6.3 & 0.2 & 5.27 & 0.09 \\
\hline $\mathrm{F} 2$ & 47.7 & 3.0 & 21.3 & 0.5 & 4.26 & 0.10 & 3.12 & 0.09 & 44.7 & 2.2 & 9.0 & 0.5 & 6.6 & 0.3 & 4.99 & 0.08 \\
\hline F3 & 57.3 & 1.3 & 27.8 & 0.5 & 5.20 & 0.14 & 4.20 & 0.10 & 48.4 & 0.4 & 9.1 & 0.2 & 7.3 & 0.1 & 5.34 & 0.10 \\
\hline F4 & 66.0 & 1.0 & 31.0 & 0.4 & 5.39 & 0.09 & 4.42 & 0.06 & 47.0 & 0.5 & 8.2 & 0.1 & 6.7 & 0.1 & 5.76 & 0.04 \\
\hline F5 & 52.4 & 1.5 & 26.2 & 0.8 & 5.12 & 0.28 & 3.89 & 0.19 & 49.9 & 1.3 & 9.8 & 0.7 & 7.4 & 0.3 & 5.11 & 0.26 \\
\hline F6 & 55.7 & 1.8 & 33.1 & 1.1 & 5.00 & 0.16 & 5.06 & 0.18 & 59.4 & 0.1 & 9.0 & 0.0 & 9.1 & 0.2 & 6.62 & 0.03 \\
\hline F7 & 58.4 & 2.1 & 25.5 & 0.5 & 4.40 & 0.30 & 3.60 & 0.20 & 43.7 & 0.8 & 7.5 & 0.6 & 6.2 & 0.3 & 5.85 & 0.46 \\
\hline
\end{tabular}

intermediate or late developmental stages. No clear ontogenetic pattern, however, was observed in $S$. curacaoense, probably due to individual variability between egg clutches produced by different females. The absolute values of $\mathrm{W}$ and $\mathrm{CHN}$ (in $\mu \mathrm{g}$ per egg) were about twice as high in $S$. curacaoense as in $S$. rectum. Also, the relative values of $\mathrm{C}$ and $\mathrm{H}$ (in $\%$ of $\mathrm{W})$ and the C:N mass ratio were lower in $S$. rectum than in $S$. curacaoense, while the percentage $\mathrm{N}$ values were similar or higher in $S$. rectum (Table 1).

\section{Biomass and elemental composition of freshly hatched zoea I larvae}

Intra- and interspecific variations in the initial biomass and elemental composition of freshly hatched larvae are shown in Table 2. Comparing the average levels of initial larval biomass and elemen- tal composition among different species, the same patterns as in egg biomass can be seen (Table 2; cf. Table 1). Again, all average amounts of biomass (W, CHN per individual), most percentage values of $\mathrm{C}$ and $\mathrm{H}$, and all C:N ratios were lower in $S$. rectum than in $S$. curacaoense; the percentage $\mathrm{N}$ values, in contrast, were generally higher in $S$. rectum.

\section{Ontogenetic changes in biomass and elemental composition during larval growth}

Under constant rearing conditions $\left(25 \%, 24^{\circ} \mathrm{C}\right)$, most larvae of Sesarma rectum moulted on the second day after hatching to the zoea II stage, 2-3 days later to the zoea III, and again 3-4 days later to the megalopa. The latter required about 10-12 days to reach metamorphosis to the juvenile crab. High mortality in the final larval moult and previous sampling

TABLE 3. - Sesarma rectum: Ontogenetic changes in biomass, elemental composition (dry mass, W; carbon, C; nitrogen, N; hydrogen, H; $\mathrm{C}: \mathrm{N}$ mass ratio) during larval growth from hatching to metamorphosis; $\mathrm{x} \pm \mathrm{SD}$, mean \pm 1 standard deviation $(\mathrm{n}=5)$.

\begin{tabular}{|c|c|c|c|c|c|c|c|c|c|c|c|c|c|c|c|c|c|}
\hline \multirow[t]{2}{*}{ Stage } & \multirow[t]{2}{*}{ Day } & \multicolumn{2}{|c|}{$\mathrm{W}(\mu \mathrm{g} / \mathrm{ind})$} & \multicolumn{2}{|c|}{$\mathrm{C}(\mu \mathrm{g} / \mathrm{ind})$} & \multicolumn{2}{|c|}{$\mathrm{N}(\mu \mathrm{g} /$ ind $)$} & \multicolumn{2}{|c|}{$\mathrm{H}(\mu \mathrm{g} /$ ind $)$} & \multicolumn{2}{|c|}{$\mathrm{C}(\% \mathrm{~W})$} & \multicolumn{2}{|c|}{$\mathrm{N}(\% \mathrm{~W})$} & \multicolumn{2}{|c|}{$\mathrm{H}(\% \mathrm{~W})$} & \multicolumn{2}{|c|}{$\mathrm{C}: \mathrm{N}$ ratio } \\
\hline & & $x^{\prime}$ & $\pm \mathrm{SD}$ & $\mathrm{x}$ & $\pm \mathrm{SD}$ & $x^{\prime}$ & $\pm \mathrm{SD}$ & $\mathrm{X}$ & $\pm \mathrm{SD}$ & $\mathrm{X}$ & $\pm \mathrm{SD}$ & $\mathrm{x}$ & $\pm \mathrm{SD}$ & $\mathrm{x}$ & $\pm \mathrm{SD}$ & $\mathrm{X}$ & $\pm \mathrm{SD}$ \\
\hline \multirow[t]{2}{*}{ Zoea I } & 0 & 25.3 & 0.7 & 10.2 & 0.3 & 2.4 & 0.1 & 1.4 & 0.1 & 40.2 & 0.3 & 9.3 & 0.1 & 5.7 & 0.1 & 4.30 & 0.02 \\
\hline & 1 & 28.6 & 0.2 & 11.3 & 0.1 & 2.7 & 0.0 & 1.6 & 0.0 & 39.3 & 0.2 & 9.5 & 0.1 & 5.5 & 0.1 & 4.16 & 0.03 \\
\hline \multirow[t]{3}{*}{ Zoea II } & 0 & 36.9 & 0.5 & 13.3 & 0.2 & 3.2 & 0.0 & 1.9 & 0.1 & 36.1 & 0.1 & 8.7 & 0.1 & 5.1 & 0.1 & 4.14 & 0.02 \\
\hline & 1 & 46.6 & 1.6 & 18.2 & 0.8 & 4.1 & 0.2 & 2.7 & 0.1 & 39.0 & 0.4 & 8.9 & 0.1 & 5.7 & 0.1 & 4.40 & 0.02 \\
\hline & 2 & 52.4 & 4.3 & 19.4 & 1.8 & 4.7 & 0.3 & 2.8 & 0.3 & 37.0 & 1.5 & 8.9 & 0.3 & 5.3 & 0.3 & 4.16 & 0.10 \\
\hline \multirow[t]{4}{*}{ Zoea III } & 0 & 50.3 & 3.0 & 18.0 & 1.0 & 4.4 & 0.2 & 2.6 & 0.2 & 35.8 & 0.6 & 8.7 & 0.1 & 5.2 & 0.1 & 4.10 & 0.03 \\
\hline & 1 & 61.8 & 2.6 & 21.6 & 2.5 & 5.0 & 0.7 & 3.1 & 0.4 & 35.0 & 3.4 & 8.1 & 0.9 & 5.0 & 0.5 & 4.27 & 0.05 \\
\hline & 2 & 63.7 & 1.9 & 23.4 & 1.1 & 5.6 & 0.3 & 3.3 & 0.1 & 36.8 & 1.1 & 8.7 & 0.3 & 5.3 & 0.2 & 4.22 & 0.09 \\
\hline & 3 & 63.6 & 4.1 & 24.4 & 1.7 & 6.0 & 0.2 & 3.6 & 0.3 & 38.4 & 0.7 & 9.5 & 0.4 & 5.7 & 0.2 & 4.04 & 0.16 \\
\hline \multirow[t]{7}{*}{ Megalopa } & 0 & 64.1 & 2.2 & 24.9 & 0.9 & 6.2 & 0.2 & 3.8 & 0.2 & 38.8 & 1.0 & 9.7 & 0.2 & 5.9 & 0.2 & 3.99 & 0.03 \\
\hline & 1 & 87.5 & 4.3 & 32.1 & 1.2 & 7.2 & 0.2 & 4.7 & 0.2 & 36.7 & 0.6 & 8.3 & 0.2 & 5.3 & 0.1 & 4.45 & 0.07 \\
\hline & 2 & 89.5 & 10.0 & 34.1 & 1.6 & 7.6 & 0.2 & 5.1 & 0.3 & 39.3 & 3.0 & 8.6 & 0.8 & 5.7 & 0.4 & 4.58 & 0.09 \\
\hline & 4 & 105.8 & 5.1 & 39.7 & 2.1 & 8.3 & 0.3 & 5.7 & 0.4 & 37.5 & 0.4 & 7.9 & 0.2 & 5.3 & 0.1 & 4.76 & 0.10 \\
\hline & 6 & 112.3 & 7.5 & 43.4 & 3.5 & 9.4 & 0.6 & 6.1 & 0.6 & 38.6 & 0.5 & 8.3 & 0.1 & 5.1 & 0.1 & 4.63 & 0.12 \\
\hline & 8 & 110.1 & 5.5 & 42.6 & 2.8 & 9.4 & 0.4 & 6.1 & 0.4 & 38.7 & 1.0 & 8.6 & 0.2 & 5.5 & 0.1 & 4.51 & 0.09 \\
\hline & 10 & 109.8 & 3.9 & 42.7 & 3.5 & 9.7 & 0.5 & 6.1 & 0.5 & 38.9 & 2.3 & 8.9 & 0.2 & 5.5 & 0.4 & 4.38 & 0.19 \\
\hline
\end{tabular}


of larvae for $\mathrm{CHN}$ analyses severely reduced the number of available materials, precluding further study of growth beyond the megalopa stage.

Ontogenetic changes in biomass and elemental composition occurring in $S$. rectum during the period from hatching to metamorphosis are documented in Table 3. Larval growth is further illustrated in Figure 1, using the carbon content and the $\mathrm{C}: \mathrm{N}$ mass ratio as examples for patterns in absolute growth (in $\mu \mathrm{g}$ per individual) and in the proportional composition of biomass respectively. These patterns are compared with previously observed growth in the congener S. curacaoense (Fig. 1). Since the data for the latter species were displayed only graphically in the original paper by Anger and Schultze (1995), they are now fully documented in Table 4, allowing for more detailed interspecific comparisons of biomass data. In S. curacaoense, early juvenile growth could also be studied; the data of juvenile biomass are thus included in Table 4 and partially illustrated in Figure 1.

In $S$. rectum, the rate of growth (measured as stage-specific increments in $\mathrm{W}$ and $\mathrm{CHN}$ per individual) was low in the first zoeal stage (11-14\%) but increasing in the subsequent stages (Table 3, Fig. 1). The zoea II added about $42-47 \%$ to its initial (postmoult) biomass, and increases of $26-38 \%$ were measured in the zoea III stage. The megalopa also showed rapid growth throughout the first 6 days of its moulting cycle, but stagnant biomass values thereafter. In each zoeal stage, the percentage increments in $\mathrm{W}, \mathrm{C}, \mathrm{N}$, and $\mathrm{H}$ were similar, so the elemental composition of body mass (proportions of $\mathrm{CHN}$ in \% of $\mathrm{W}$ ) remained fairly constant throughout the zoeal phase. The megalopa, by contrast, accumulated higher amounts of total $\mathrm{W}(75 \%)$ and $\mathrm{C}$ (74\%) during its first 6 days as compared to $\mathrm{H}$ $(60 \%)$ and $\mathrm{N}(52 \%)$. This implies changes in the relative composition of biomass in this stage, which are primarily reflected by higher average $\mathrm{C}: \mathrm{N}$ ratios (Table 3, Fig. 1). This index showed also a conspicuous pattern of change during the megalopal moulting cycle, namely a rapid increase during the first half (i.e. in the postmoult and intermoult stages) and gradually decreasing values thereafter (in premoult; see Fig. 1).

In $S$. curacaoense, larval biomass at hatching was 2-3 times higher than in $S$. rectum, but subsequent growth rates were lower. Its two zoeal stages combined gained $45 \%$ in $\mathrm{N}, 25 \%$ in $\mathrm{H}, 16 \%$ in $\mathrm{C}$, and only $12 \%$ in total W (Table 4). As a consequence of these differential increases, zoeal biomass
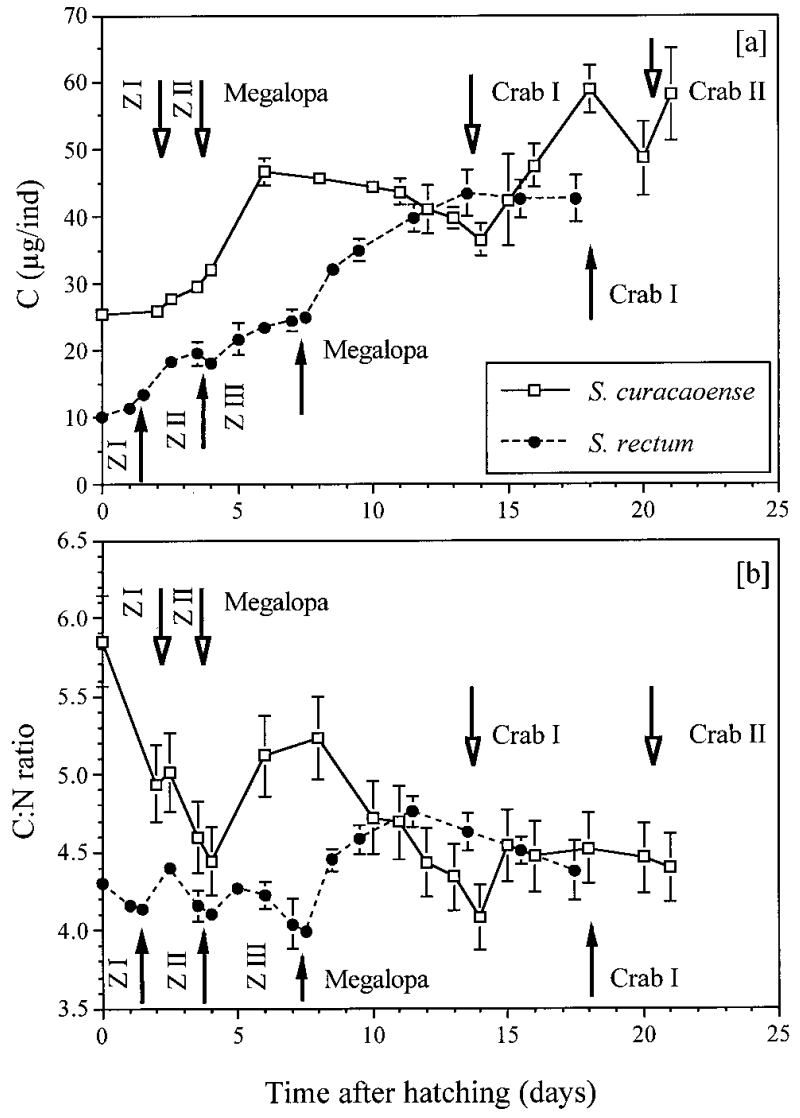

FIG. 1. - Comparison of larval growth patterns in two Sesarmidae species, Sesarma rectum (filled symbols, present study) and $S$. curacaoense (open symbols, data from Anger and Schultze, 1995; also comprising early juvenile growth): changes in [a] carbon content $(\mathrm{C}, \mu \mathrm{g} /$ individual), [b] $\mathrm{C}: \mathrm{N}$ mass ratio; moults to successive developmental stages are indicated with arrows; error bars: mean values $\pm 1 \mathrm{SD}(\mathrm{n}=5)$

showed an increasing percentage of $\mathrm{N}$ and a decreasing C:N ratio (Table 4, Fig. 1). The megalopa differed substantially from the zoeal stages, showing a rapid initial biomass accumulation during the postmoult and early intermoult periods. This growth was considerably higher in total $\mathrm{W}(52 \%)$ and in the fractions of $\mathrm{C}(42 \%)$ and $\mathrm{H}(41 \%)$ as compared to $\mathrm{N}$ $(22 \%)$. After reaching a maximum on day 4 , megalopal biomass remained stagnant or decreased prior to metamorphosis. Since these changes were always more pronounced in $\mathrm{C}$ than in $\mathrm{N}$, they are clearly reflected by changing $\mathrm{C}: \mathrm{N}$ values (Table 4 ).

In summary, larval growth patterns in the two Sesarma species compared here are similar in showing low growth rates immediately after hatching, maximum growth during the first half of the megalopa moulting cycle, and stagnant or declining biomass prior to metamorphosis (Fig. 1). As major differences, we found that larval growth in $S$. curacaoense remained low throughout its abbreviated zoeal phase (with only two stages, passed 
TABLE 4. - Sesarma curacaoense: Ontogenetic changes in biomass, elemental composition (dry mass, W; carbon, C; nitrogen, N; hydrogen, $\mathrm{H} ; \mathrm{C}: \mathrm{N}$ mass ratio) during larval growth from hatching to the crab II stage; data from Anger and Schultze, 1995; \pm SD, mean \pm 1 standard deviation $(\mathrm{n}=5)$.

\begin{tabular}{|c|c|c|c|c|c|c|c|c|c|c|c|c|c|c|c|c|c|}
\hline \multirow[t]{2}{*}{ Stage } & \multirow[t]{2}{*}{ Day } & \multicolumn{2}{|c|}{$\mathrm{W}$ ( $\mu \mathrm{g} /$ ind $)$} & \multicolumn{2}{|c|}{$\mathrm{C}(\mu \mathrm{g} / \mathrm{ind})$} & \multicolumn{2}{|c|}{$\mathrm{N}(\mu \mathrm{g} / \mathrm{ind})$} & \multicolumn{2}{|c|}{$\mathrm{H}(\mu \mathrm{g} / \mathrm{ind})$} & \multicolumn{2}{|c|}{$\mathrm{C}(\% \mathrm{~W})$} & \multicolumn{2}{|c|}{$\mathrm{N}(\% \mathrm{~W})$} & \multicolumn{2}{|c|}{$\mathrm{H}(\% \mathrm{~W})$} & \multicolumn{2}{|c|}{$\mathrm{C}: \mathrm{N}$ ratio } \\
\hline & & $\mathrm{x}$ & $\pm \mathrm{SD}$ & $\mathrm{X}$ & $\pm \mathrm{SD}$ & $\mathrm{x}$ & $\pm \mathrm{SD}$ & $\mathrm{X}$ & $\pm \mathrm{SD}$ & $\mathrm{X}$ & $\pm \mathrm{SD}$ & $\mathrm{X}$ & $\pm \mathrm{SD}$ & $\mathrm{X}$ & $\pm \mathrm{SD}$ & $\mathrm{X}$ & $\pm \mathrm{SD}$ \\
\hline \multirow[t]{2}{*}{ Zoea I } & 0 & 58.4 & 2.1 & 25.5 & 0.5 & 4.4 & 0.3 & 3.6 & 0.2 & 43.7 & 0.8 & 7.5 & 0.6 & 6.2 & 0.3 & 5.85 & 0.46 \\
\hline & 2 & 54.7 & 2.2 & 25.9 & 1.0 & 5.3 & 0.3 & 3.8 & 0.2 & 47.3 & 1.3 & 9.6 & 0.7 & 6.9 & 0.4 & 4.94 & 0.27 \\
\hline \multirow[t]{2}{*}{ Zoea II } & 0 & 60.3 & 1.7 & 27.7 & 0.9 & 5.5 & 0.1 & 4.0 & 0.2 & 45.9 & 1.2 & 9.2 & 0.3 & 6.7 & 0.3 & 5.01 & 0.12 \\
\hline & 3 & 65.2 & 2.4 & 29.5 & 1.4 & 6.4 & 0.2 & 4.5 & 0.2 & 45.2 & 0.7 & 9.8 & 0.2 & 6.9 & 0.1 & 4.60 & 0.10 \\
\hline \multirow[t]{7}{*}{ Megalopa } & 0 & 68.7 & 1.6 & 32.1 & 0.7 & 7.2 & 0.3 & 4.9 & 0.4 & 46.7 & 0.1 & 10.5 & 0.4 & 7.2 & 0.5 & 4.44 & 0.15 \\
\hline & 2 & 103.6 & 2.3 & 46.6 & 2.1 & 9.1 & 0.8 & 7.3 & 0.8 & 44.9 & 1.3 & 8.8 & 0.6 & 7.0 & 0.6 & 5.12 & 0.24 \\
\hline & 4 & 104.1 & 2.1 & 45.7 & 1.5 & 8.8 & 0.2 & 6.9 & 0.2 & 43.9 & 1.0 & 8.4 & 0.2 & 6.6 & 0.2 & 5.23 & 0.03 \\
\hline & 6 & 101.9 & 2.3 & 44.3 & 0.8 & 9.4 & 0.4 & 6.8 & 0.2 & 43.5 & 0.4 & 9.2 & 0.4 & 6.6 & 0.2 & 4.72 & 0.16 \\
\hline & 7 & 102.8 & 3.3 & 43.7 & 1.9 & 9.3 & 0.2 & 6.7 & 0.4 & 42.5 & 0.6 & 9.1 & 0.1 & 6.5 & 0.2 & 4.69 & 0.12 \\
\hline & 8 & 98.1 & 6.3 & 41.0 & 3.5 & 9.3 & 0.5 & 6.3 & 0.5 & 41.7 & 1.1 & 9.5 & 0.6 & 6.4 & 0.2 & 4.43 & 0.37 \\
\hline & 9 & 94.7 & 3.3 & 39.8 & 1.6 & 9.2 & 0.2 & 6.0 & 0.3 & 42.0 & 0.3 & 9.7 & 0.1 & 6.4 & 0.1 & 4.34 & 0.07 \\
\hline \multirow[t]{5}{*}{ Crab I } & 0 & 92.2 & 5.7 & 36.5 & 2.4 & 9.0 & 0.4 & 5.7 & 0.3 & 39.6 & 0.8 & 9.7 & 0.3 & 6.1 & 0.2 & 4.08 & 0.11 \\
\hline & 1 & 115.1 & 18.6 & 42.4 & 6.8 & 9.3 & 1.5 & 6.3 & 1.1 & 36.8 & 0.3 & 8.1 & 0.3 & 5.5 & 0.2 & 4.54 & 0.17 \\
\hline & 2 & 128.7 & 8.3 & 47.5 & 3.2 & 11.1 & 0.6 & 7.3 & 0.4 & 36.9 & 0.8 & 8.3 & 0.5 & 5.7 & 0.1 & 4.47 & 0.35 \\
\hline & 4 & 155.4 & 7.7 & 58.9 & 3.6 & 13.0 & 0.5 & 9.0 & 0.5 & 37.9 & 0.5 & 8.4 & 0.2 & 5.8 & 0.1 & 4.52 & 0.19 \\
\hline & 6 & 127.3 & 11.3 & 48.6 & 5.5 & 11.2 & 1.8 & 7.1 & 0.9 & 38.1 & 2.2 & 8.8 & 0.8 & 5.6 & 0.3 & 4.46 & 0.41 \\
\hline Crab II & 1 & 152.5 & 12.5 & 58.1 & 6.9 & 13.2 & 0.7 & 8.7 & 1.0 & 38.0 & 2.0 & 8.7 & 0.4 & 5.7 & 0.2 & 4.40 & 0.32 \\
\hline
\end{tabular}

within 3-4 days), while $S$. rectum showed an increasing growth in its three zoeal stages (taking together about 7-8 days). Due to continued accumulation of biomass in $S$. rectum, this species is capable of making up for its much lower initial biomass at hatching (amounting to only about one third to one half of the values measured in S. curacaoense). As a result, early megalopae showed similar biomass values in both species. During the megalopa stage, $S$. rectum continued to grow through a longer period than the equivalent stage of S. curacaoense (Fig. 1). As a result of these differential patterns of growth, in the late megalopa stage, prior to metamorphosis, $S$. rectum reached a larger biomass than a juvenile crab of $S$. curacaoense immediately after metamorphosis.

Interspecific differences between $S$. curacaoense and $S$. rectum can also be seen in the relative chemical composition of larval biomass. Most conspicuously, S. curacaoense showed a higher C:N ratio at hatching ( $5.85 \pm 0.46$ vs. $4.30 \pm 0.02)$, followed by steeply decreasing values throughout the zoeal stages, while constantly low figures were observed in $S$. rectum. By the end of the zoeal phase, the difference in the $\mathrm{C}: \mathrm{N}$ ratio of the two species had almost disappeared (Fig. 1). The megalopae showed similar patterns of change in the $\mathrm{C}: \mathrm{N}$ index in both species, although with initially higher average values in S. curacaoense. Since the megalopa of this species also showed a steeper decline during its premoult period, the $\mathrm{C}: \mathrm{N}$ ratio measured at metamorphosis was again similar in these two species.

\section{Exuvial matter and elemental composition, loss- es of larval biomass}

Data on exuvial biomass allow for both intraspecific (ontogenetic) and interspecific comparisons of the elemental composition of exuvial matter (Table 5). The biomass values per exuvia may be further compared in relation to total larval biomass in late premoult. All percentage $\mathrm{CHN}$ values as well as the exuvial $\mathrm{C}: \mathrm{N}$ ratios indicate quite clearly that the chemical composition of the exuviae differs greatly from that of whole larval body mass (Table 5; cf. Tables 3,4). All exuvial CHN values (in \% of $\mathrm{W}$ ) were lower than in total body mass of the corresponding larval stages.

In successive larval stages, both species consistently showed an increase in $\mathrm{W}$ and $\mathrm{CHN}$ per exuvia, reflecting increasing larval size and biomass, while the percentage values of $\mathrm{CHN}$ (in \% of exuvial W) decreased (Table 5). However, the differences in exuvial biomass between equivalent stages of $S$. rectum and $S$. curacaoense were generally smaller than would be expected from differences in total larval biomass (Fig. 1a).

When exuvial biomass is expressed as a percentage of larval biomass shortly before moulting (\% of late premoult matter, LPM), we obtain a more immediately comparable measure of exuvial losses in different stages and species. These scaled values increased almost consistently in both species among successive larval stages (only exception: $\mathrm{N}$ in the zoeal stages of $S$. rectum; Table 5). When the exu- 
TABLE 5. - Biomass, elemental composition (dry mass, W; carbon, C; nitrogen, N; hydrogen, H; C:N mass ratio) of larval exuviae, ecdysial losses (\% of late premoult matter, LPM) in two Sesarmidae species; $\mathrm{x} \pm \mathrm{SD}$, mean \pm 1 standard deviation $(\mathrm{n}=5)$.

\begin{tabular}{|c|c|c|c|c|c|c|c|c|c|c|c|c|}
\hline \multirow[t]{2}{*}{ Exuvia } & \multirow[t]{2}{*}{ Species } & \multirow[t]{2}{*}{ larval stage } & \multicolumn{2}{|c|}{ W } & \multicolumn{2}{|c|}{$\mathrm{C}$} & \multicolumn{2}{|c|}{$\mathrm{N}$} & \multicolumn{2}{|c|}{$\mathrm{H}$} & \multicolumn{2}{|c|}{$\mathrm{C}: \mathrm{N}$ ratio } \\
\hline & & & $\mathrm{x}$ & $\pm \mathrm{SD}$ & $\mathrm{x}$ & $\pm \mathrm{SD}$ & $\mathrm{x}$ & $\pm \mathrm{SD}$ & $\mathrm{x}$ & $\pm \mathrm{SD}$ & $\mathrm{x}$ & $\pm \mathrm{SD}$ \\
\hline \multirow{6}{*}{$\begin{array}{l}\text { Biomass } \\
\text { ( } \mu \mathrm{g} / \text { individual) }\end{array}$} & \multirow[t]{3}{*}{ S. rectum } & zoea I & 1.3 & 0.1 & 0.38 & 0.02 & 0.07 & 0.00 & 0.04 & 0.00 & & \\
\hline & & zoea II & 3.2 & 0.1 & 0.70 & 0.02 & 0.09 & 0.01 & 0.10 & 0.00 & & \\
\hline & & zoea III & 4.8 & 0.2 & 1.03 & 0.03 & 0.15 & 0.01 & 0.15 & 0.01 & & \\
\hline & \multirow[t]{3}{*}{ S. curacaoense } & zoea I & 1.2 & 0.1 & 0.43 & 0.04 & 0.09 & 0.01 & 0.05 & 0.01 & & \\
\hline & & zoea II & 2.7 & 0.2 & 0.73 & 0.04 & 0.12 & 0.01 & 0.09 & 0.01 & & \\
\hline & & megalopa & 16.2 & 2.0 & 3.15 & 0.29 & 0.62 & 0.04 & 0.48 & 0.10 & & \\
\hline \multirow{6}{*}{$\begin{array}{l}\text { Composition } \\
(\% \text { of } \mathrm{W})\end{array}$} & \multirow[t]{3}{*}{ S. rectum } & zoea I & & & 28.7 & 1.5 & 5.2 & 0.4 & 3.3 & 0.1 & 5.5 & 0.2 \\
\hline & & zoea II & & & 22.0 & 0.6 & 3.0 & 0.1 & 3.0 & 0.1 & 7.5 & 0.2 \\
\hline & & zoea III & & & 21.7 & 0.8 & 3.1 & 0.1 & 3.1 & 0.0 & 6.9 & 0.1 \\
\hline & \multirow[t]{3}{*}{ S. curacaoense } & zoea I & & & 36.2 & 3.0 & 7.6 & 1.0 & 4.1 & 0.6 & 4.6 & 0.5 \\
\hline & & zoea II & & & 27.7 & 1.6 & 4.6 & 0.5 & 3.4 & 0.3 & 6.0 & 0.4 \\
\hline & & megalopa & & & 19.5 & 1.6 & 3.8 & 0.4 & 3.0 & 0.8 & 5.2 & 0.3 \\
\hline \multirow{6}{*}{$\begin{array}{l}\text { Loss } \\
\text { (\% of LPM) }\end{array}$} & \multirow[t]{3}{*}{ S. rectum } & zoea I & 4.6 & & 3.4 & & 2.6 & & 2.5 & & & \\
\hline & & zoea II & 6.1 & & 3.6 & & 1.9 & & 3.6 & & & \\
\hline & & zoea III & 7.5 & & 4.2 & & 2.5 & & 4.1 & & & \\
\hline & \multirow[t]{3}{*}{ S. curacaoense } & zoea I & 2.2 & & 1.7 & & 1.8 & & 1.2 & & & \\
\hline & & zoea II & 4.1 & & 2.5 & & 1.9 & & 2.1 & & & \\
\hline & & megalopa & 17.1 & & 7.9 & & 6.8 & & 7.9 & & & \\
\hline
\end{tabular}

vial losses in \% of LPM are compared between equal stages of the two species (this is possible only for the zoea I and II stages), generally higher values can be seen in $S$. rectum as compared to $S$. curacaoense (Table 5; only exception: $\mathrm{N}$ in the zoea II).

\section{DISCUSSION}

Our study provides the first data concerning biomass and elemental composition (CHN) of the eggs and larvae of Sesarma rectum, and these can now be compared to available or future observations for other neotropical Sesarmidae. In all these bioenergetic traits of the early life-history stages as well as in its mode of larval development, $S$. rectum takes an intermediate position between Armases spp. (Anger and Moreira, 2002) and S. curacaoense (present study; Anger and Schultze, 1995). While most Armases spp. show a relatively extended mode of larval development with four (exceptionally three) zoeal stages, S. rectum passes invariably through three, and $S$. curacaoense through only two. This sequence of increasingly abbreviated larval development corresponds to increasing independence from the ancestral marine environment, which is also indicated by differential degrees of larval salinity tolerance and independence from planktonic food sources (see Anger, 2001).

While euryhalinity in decapod crustacean larvae is based on an early appearance of osmoregulatory functions (Charmantier, 1998; Charmantier et al., 1998, 2002; Anger and Charmantier, 2000; Anger,
2003), tolerance of food limitation in non-marine habitats requires an enhanced female energy investment in egg production, i.e. high amounts of yolk reserves remaining through embryogenesis until hatching (Anger, 2001). In the biomass of individual eggs and freshly hatched larvae, S. rectum shows clearly higher values than Armases angustipes (with 4 zoeal stages; Anger and Moreira, 2002), but lower values than A. miersii (3 zoeal stages) or S. curacaoense (2 zoeal stages; Anger and Schultze, 1995). Although the adults of all these species are similar in their ecology, all living in brackish water habitats such as mangrove swamps or estuaries and all showing semiterrestrial behaviour, their larvae differ in the degree of lecithotrophy and thus in their dependence on planktonic food. When freshly hatched larvae of these species are kept without food, they are maximally capable of reaching the zoea II ( $A$. angustipes), the zoea III (A. miersii, S. rectum), or the megalopa stage (S. curacaoense) (Anger, 2001, p. 111).

This sequence in the degree of developmental abbreviation and in larval lecithotrophy may be further continued with the fully terrestrial bromeliad crab, Metopaulias depressus. Its two zoeal stages are non-feeding, developing exclusively with energy reserves remaining from the egg to the megalopa stage (Anger and Schuh, 1992). Although the megalopa of this species eats when food is available, its development through metamorphosis to the first juvenile crab stage is in principal also food-independent (facultative lecithotrophy). This unusual capability is based on an extremely large biomass of eggs 
and early larvae, with lipids serving as an energyrich endogenous fuel for development. From initial biomass and elemental composition in the eggs and early larvae, it would appear that a similar mode of development may also be expected in S. fossarum and in other endemic Jamaican sesarmid species (Anger, 2001). Since S. cuaracaoense is considered to be a close relative of the ancestral species from which the Jamaican freshwater and terrestrial species evolved (Hartnoll, 1964; Schubart et al., 1998), we may assume that an abbreviated development with only two zoeal stages as well as an enhanced larval size, biomass and lipid content already existed in the ancestral crab species that gave rise to the adaptive radiation on Jamaica. Compared with this clade, S. rectum is much closer to the "normal" (i.e. extended and planktotrophic) end of the continuum of reproductive traits among the neotropical Sesarmidae.

Our comparison of larval growth patterns in two close relatives with differential degrees of developmental abbreviation and lecithotrophy, S. rectum and $S$. curacaoense, showed that a high endotrophic potential is associated with low zoeal growth rates (Fig. 1). This is probably due to partial utilisation of large internal energy reserves, even in the presence of food. Larvae with lower initial energy reserves, in contrast, should depend on a more continuous and efficient utilisation of external food sources. While S. rectum starts its larval development with only about half the biomass initially found in S. curacaoense, it is capable of catching up while it develops through an additional zoeal stage, also taking a longer time in each moulting cycle. As a result of both higher growth rates and a longer growth period, both species become similar in biomass when they approach metamorphosis. Similar compensatory larval growth patterns were also found in a comparison between two congeners with relatively extended or abbreviated development, Armases angustipes and A. miersii respectively (Anger and Moreira, 2002).

As another mechanism favouring food-independent larval development, there appears to be an energy-saving production of especially thin exuviae with low biomass in some species. This was observed in the fully lecithotrophic zoeae of the bromeliad crab, Metopaulias depressus (Anger and Schuh, 1992), in facultatively lecithotrophic zoeae of $S$. curacaoense (Anger and Schultze, 1995) and A. miersii (Anger and Moreira, 2002), and in other non-feeding decapod crustacean larvae (Anger, 2001). Also in this developmental trait (see Table 5), the present study showed $S$. rectum to be at an intermediate level among the Sesarmidae for which comparative data are available.

In conclusion, our interspecific comparison of the biomass content and elemental composition of eggs and larvae suggests that $S$. rectum has become partially independent of the sea. Its initial energy reserves should allow for a limited retention of its larvae within the parental environment, i.e. in partially land-locked coastal mangrove swamps, where plankton production is highly variable or unpredictable. Although the endotrophic potential of this species is higher than in many other sesarmid crabs including A. angustipes (co-occurring with $S$. rectum in the same habitat; Coelho and Ramos-Porto, 1981, Fimpel, 1975; Prado, 1999), its independence from planktonic food is clearly weaker than in the congener S. curacaoense, where non-feeding development may pass from hatching to the megalopa. Since this semibenthic larval stage has access to other (namely benthic) food sources, the entire life cycle of $S$. curacaoense may be closed within the parental mangrove habitat. $S$. rectum, in contrast, can maximally reach the zoea III in absence of food (Anger, 2001), implying that planktonic food is necessary for successful development beyond this stage. Hence, a limited larval export towards coastal marine waters should occur in this species, with development probably occurring in the lower reaches of coastal mangrove lagoons.

\section{ACKNOWLEDGEMENTS}

We wish to thank the staff of the CEBIMar for kind hospitality and support of our study, Mrs. C. Püschel (Helgoland) for carrying out CHN analyses, and Dr. L. Giménez and Lic. G. Torres for correcting the Spanish summary. The first author acknowledges financial support from the German Academic Exchange Service, DAAD (Bonn), and Coordenadoria de Aperfeiçoamento de Pessoal do Ensino Superior, CAPES (Brasilia).

\section{REFERENCES}

Abele, L.G. - 1973. Taxonomy, distribution and ecology of the genus Sesarma (Crustacea, Decapoda, Grapsidae) in the eastern North America, with special reference to Florida. Am. Midl. Nat., 90: 375-386.

Anger, K. - 1995. Starvation resistance in larvae of a semiterrestrial crab, Sesarma curacaoense (Decapoda: Grapsidae). J. Exp. 
Mar. Biol. Ecol., 187: 161-174.

Anger, K. - 2001. The biology of decapod crustacean larvae. Crustacean Issues Vol. 14. A.A. Balkema, Lisse, The Netherlands.

Anger, K. - 2003. Salinity as a key parameter in the larval biology of decapod crustaceans. Invertebr. Reprod. Dev., 43: 29-45.

Anger, K. and G. Charmantier. - 2000. Ontogeny of osmoregulation and salinity tolerance in a mangrove crab, Sesarma curacaoense (Decapoda: Grapsidae). J. Exp. Mar. Biol. Ecol., 251: 265-274.

Anger, K. and G.S. Moreira. - 2002. Patterns of larval and early juvenile growth in a semiterrestrial crab, Armases angustipes (Decapoda: Sesarmidae): comparison with a congener with abbreviated development. Mar. Biol., 141: 733-740.

Anger, K., D. Schreiber and M. Montú. - 1995. Abbreviated larval development of Sesarma curacaoense (Rathbun, 1897) (Decapoda: Grapsidae) reared in the laboratory. Nauplius, Rio Grande (Brazil), 3: 127-154

Anger, K. and M. Schuh. - 1992. Bioenergetics of abbreviated larval development in the bromelid crab, Metopaulias depressus (Decapoda: Grapsidae). Comp. Biochem. Physiol., 103A: 507-518.

Anger, K. and K. Schultze. - 1995. Elemental composition (CHN), growth, and exuvial loss in the larval stages of two semiterrestrial crabs, Sesarma curacaoense and Armases miersii (Decapoda: Grapsidae). Comp. Biochem. Physiol., 111A: 615-623.

Charmantier, G. - 1998. Ontogeny of osmoregulation in crustaceans: a review. Invertebr. Reprod. Dev., 33: 177-190.

Charmantier, G., M. Charmantier-Daures and K. Anger. - 1998. Ontogeny of osmoregulation in the grapsid crab Armases miersii (Crustacea, Decapoda). Mar. Ecol. Prog. Ser. 164: 285-292.

Charmantier, G., L. Giménez, M. Charmantier-Daures, and K. Anger. - 2002. Ontogeny of osmoregulation, physiological plasticity, and larval export strategy in the grapsid crab Chasmagnathus granulata (Crustacea, Decapoda). Mar. Ecol. Prog. Ser., 229: 185-194.

Coelho, P.A. - 1966. Algumas observações sôbre o habitat de Sesarma rectum (Crustácea, Decapoda, Grapsidae) em Pernambuco. Ciência e Cultura, 18: 244.

Coelho, P.A. and M. Ramos-Porto. - 1981. Grapsidae do genero Sesarma do norte e nordeste do Brasil (Crustacea, Decapoda) com especial referencia a Pernambuco. Anais do III Encontro de Zoologia do Nordeste, 176-185.

Costlow, J.D. and C.G. Bookhout. - 1962. The larval development of Sesarma reticulatum Say reared in the laboratory. Crustaceana, 4: 281-294.
Fimpel, E. - 1975. Phänomene der Landadaptation bei terrestrischen und semiterrestrischen Brachyura der brasilianischen Küste (Malacostraca, Decapoda). Zool. Jb. Syst., 102: 173-214.

Fransozo, A. - 1986. Desenvolvimento dos estágios juvenis de Sesarma (Holometopus) rectum Randall, 1840 (Decapoda, Grapsidae) obtidos em laboratório. Naturalia, 11/12: 77-87.

Fransozo, A. and N.J. Hebling - 1986. Desenvolvimento larval de Sesarma (Holometopus) rectum Randall, 1840 (Decapoda, Grapsidae), em laboratório. Rev. Brasil. Biol., 46: 353-364.

Gerlach, S.A. - 1958. Die Mangroveregion tropischer Küsten als Lebensraum. Z. Morph. U. Okol. Tiere, 46: 636-730.

Gore, R.H. - 1985. Molting and growth in decapod larvae. In: Wenner, A.M. (eds.), Larval Growth. Crustacean Issues. Vol. 2, pp. 1-65. Balkema, Rotterdam.

Hartnoll, R.G. - 1964. The freshwater grapsid crabs of Jamaica. Proc. Linn. Soc. Lond., 175: 145-169.

Hartnoll, R.G. - 1965. Notes on the marine grapsid crabs of Jamaica. Proc. Linn. Soc. Lond., 176: 113-147.

Prado, A., 1999. Taxonomia, distribuicão e ecologia da família Grapsidae (Crustacea, Decapoda, Brachyura) no litoral Brasileiro. PhD thesis, Universidade Estadual Paulista.

Rabalais, N.N. and R.H. Gore. - 1985. Abbreviated development in decapods. In: Wenner, A. M. (eds.), Larval Growth. Crustacean Issues. Vol. 2, pp. 67-126. Balkema, Rotterdam.

Schubart, C.D., J.A. Cuesta, R. Diesel and D.L. Felder. - 2000 Molecular phylogeny, taxonomy, and evolution of nonmarine lineages within the American grapsoid crabs (Crustacea: Brachyura). Mol. Phylogenet. Evol., 15: 179-190.

Schubart, C.D., J.A. Cuesta and D.L. Felder. - 2002. Glyptograpsidae, a new brachyuran family from Central America: larval and adult morphology, and a molecular phylogeny of the Grapsoidea. J. Crust. Biol., 22: 28-44.

Schubart, C.D., R. Diesel and S.B. Hedges. - 1998. Rapid evolution to terrestrial life in Jamaican crabs. Nature, 393: 363-365.

Wilson, K.A. - 1989. Ecology of mangrove crabs: predation, physical factors and refuges. Bull. Mar. Sci., 44: 263-273.

Zimmerman, T.L. and D.L. Felder. - 1991. Reproductive ecology of an intertidal brachyuran crab, Sesarma sp. (nr. reticulatum), from the Gulf of Mexico. Biol. Bull., 181: 387-401.

Scient. ed.: C. Froglia 